\title{
実用講座
}

\section{超音波フェイズドアレイの基本原理 ${ }^{*}$}

\author{
山 本 優一郎 ${ }^{* *}$
}

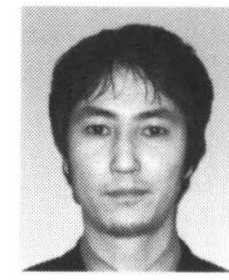

Radical principle of Phased Array*

by YAMAMOTO Yuichiro ${ }^{* *}$

キーワード＼cjkstart超音波フェイズドアレイ,リニアスキャン, セクタースキャン

\section{1.緒言}

超音波フェイズドアレイは，原理的にはフェイズドア レイレーダー, フェイズドアレイソナーなどと同様に波 動の物理的な特性を応用するものです.

超音波フェイズドアレイは，超音波探傷が適用される 市場が限られていたことや, 短い波長, モード変換, さ らには使われるコンポーネントが複雑なため他の応用分 野より開発が遅れていました。

実用的な観点から見れば, 超音波フェイズドアレイは 単に超音波の発生, 受信の方法です. しかし超音波は物 質の中では発生のプロセス（ピエゾ現象, 電磁超音波, レーザーあるいはフェイズドアレイ）とは無関係に超音 波本来の挙動を示します.

従って, 超音波検査に用いた場合も細部についてはい ずれも同一結果を示します。すなわち， $7.5 \mathrm{MHz}$ が従来 の超音波探傷で最適な検査周波数であったとすれば, フ エイズドアレイでも同じ周波数, 焦点距離, および入射 角が適切な選択となります.

フェイズドアレイでは, アレイを校正するすべての探触 子エレメントにそれぞれ独立した配線を施し, 時間差を設 けてパルス駆動します。これらのエレメントは一般に4〜 32 個のグループでドライブされ, パイプライン溶接検査で は16エレメントが1つのグループとしてドライブされます.

的確で使いやすい探傷システムを構成する為に，七ッ トアップをパルスタイミング（時間遅延值＝タイムディ レイ）を計算してオペレーターが手動入力するか，あら かじめ用意されたファイルの内容を読み込んで入射角度， 焦点距離, スキャンの要領を設定します（図 1 ).

タイムディレイは, 探傷位置への超音波の露呈時間と スキャンの容量, ビーム焦点から定まる超音波の合成法 則（Focal law）に基づいて決められます.

*原稿受付 平成17年 4 月20日

$*$ アールティテック・アジア (株) R/DTECH ASIA.inc
タイムディレイを作る電子回路は, フェイズドアレイ に必要とされる精度を確保する為に，およそ2 2.5 ns の 正確度が要求されます.

最初のセットアップ準備には時間を要することがあり ますが, それらのセットアップ情報はファイルに記録さ れ，簡単に再読み込みすることが出来ます.

また, これらのセットアップファイルの内容の変更訂 正も容易です.

\section{2.スキャンの方式}

パルス送信と受信のタイミング電子制御で, さまざま な走行パターンを作ることが出来ます.

\section{3. 電子制御のスキャン (リニアスキャン)}

アレイに沿ってドライブパターンを移動させることに よって, 超音波ビームを横移動させるリニアスキャンが 行えます (図 2 ).

アレイは128エレメントが一般的で, 8〜16のグループ でパルスドライブされます.

リニアスキャンでは, 焦点位置にあたる部位を高いビ ーム密度でカバーすることが出来ます．アレイ配置がフ ラットかつ直線の場合は, 走行パターンは単純な B スキ ヤンとなります。 また, アレイが曲線状であると, 走行 パターンも曲線状となります。

リニアスキャンはプログラミングが容易です。例えば フェイズドアレイで $45^{\circ}$ と $60^{\circ}$ の横波を用い従来の手動検 査を再現して溶接部を検査するプログラムなどは作成が 極めて容易です.

\section{4. 電子制御のスキャン（セクトリアル スキャン)}

セクトリアルスキャンは, リニアスキャンと同じセッ トのエレメントをしようしてもタイムデイレイを変更 
a. リニアスキャン

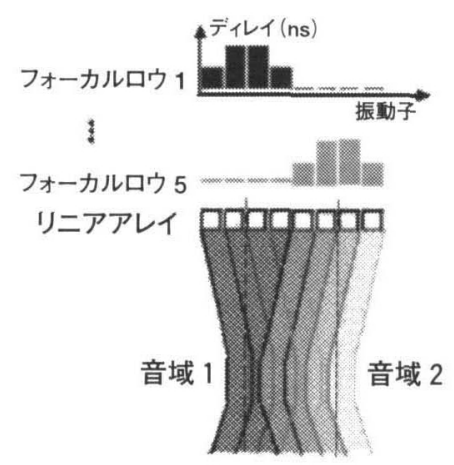

b. セクタースキャン

c. デプスフォーカシング

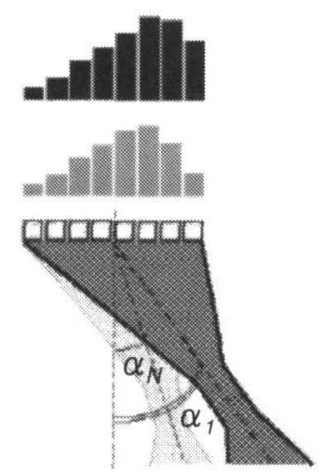

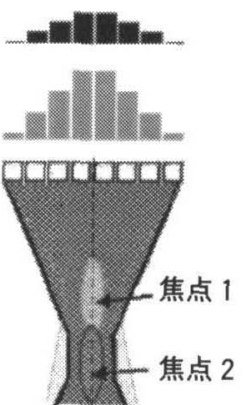

図 1 フェイズドアレイのリニアスキャン及びセクトリアルスキャンの模型図

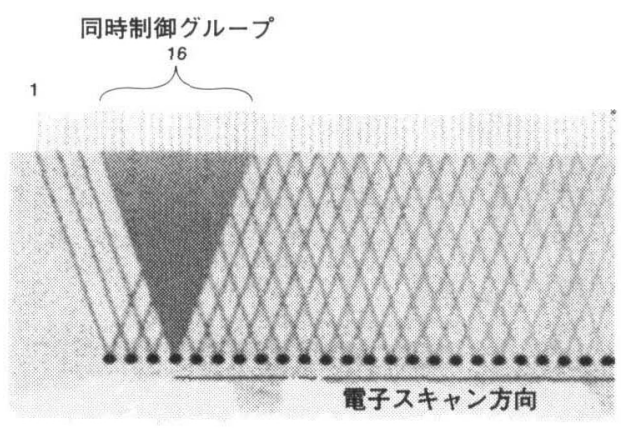

困 2 リニアスキャンの説明図

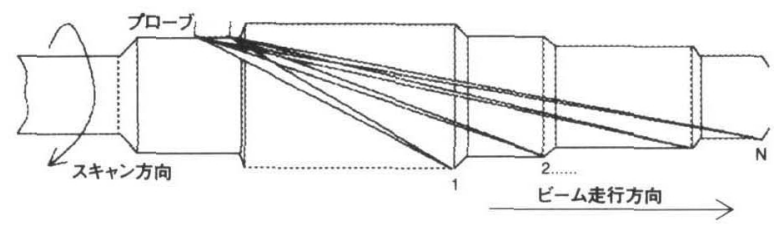

図 3 セクトリアルスキャンのタービンローターの適用例

し，ビームの入射角を変化させることで実現出来ます (図 3 ).

セクトリアルスキャンの特徵的な適用分野に, 通常の 手法なら探触子の配置が困難な部品たとえばタービンブ レードの接合部の検査があります.

セクトリアルスキャンの角度は, アレイへ加える周波 数とエレメント幅に関連しますが， $\pm 20^{\circ}$ から $\pm 80^{\circ}$ まで 振ることが出来ます。

\section{5. フェイズドアレイプローブのビーム} 特性

フェイズドアレイの利点の一つとして，自由に入射角 度を設定できることが挙げられる。しかしながら設定で きる入射角度は個々の振動子特性に依存し, 一定以上の 角度は設定できず，（図 $4 \mathrm{a}$ ）の数式にて算出されます.

また, ビーム径の算出方法は従来 UT の数式がそのま ま適用されます (図 $4 \mathrm{~b}$ ). $\cdot B$

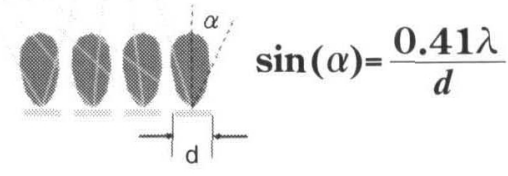

図 4a 設定有効角の模型図・算出式

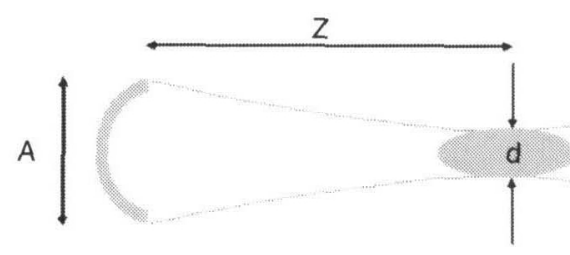

例：焦点 $50 \mathrm{~mm}, 33$ 振動子, $0.6 \mathrm{~mm}$ 幅

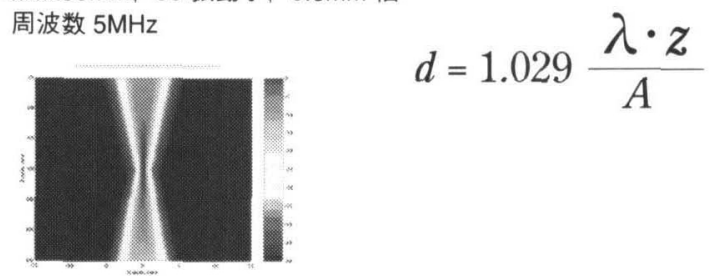

図 $4 b$ ビーム径の模型図

\section{6. スキャンの組合せ}

リニアスキャン，セクトリアルスキャン，精密なフォ 一カシングの各機能を組合せることで多様なスキャンが 可能で, 実用的で理解しやすい検査結果の表示が可能に なります（図 5 )。このように最適ビーム角を選び目的に 合った機能的なスキャニングを組合せることで溶接やコン ポーネントの検査を高速かる的確に行うことが出来ます.

このようにリニアスキャンとセクトリアルスキャンを

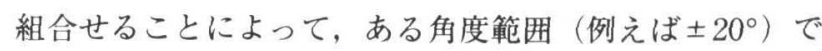
部品の超音波探傷を詳細に行うことも可能になります. この探傷方法は, 従来の単純なビームによる検査が十分 に機能しない場合，例えば欠陥が規則性を持たない航空 


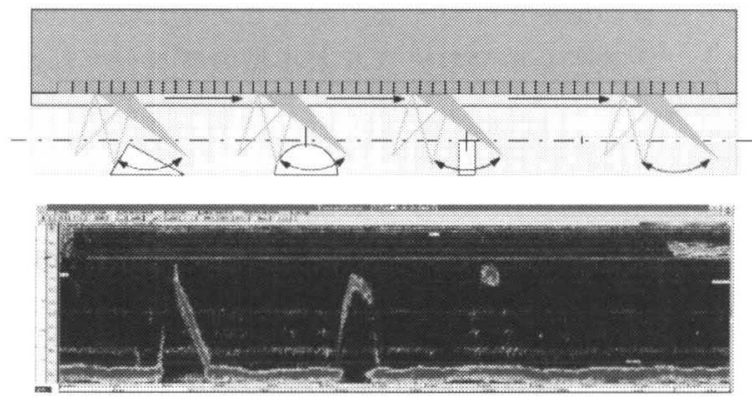

図 5 上: セクトリアルスキャンとリニアスキャンを 組合せたスキャニングパターン

下：探傷データを合成した超音波イメージ

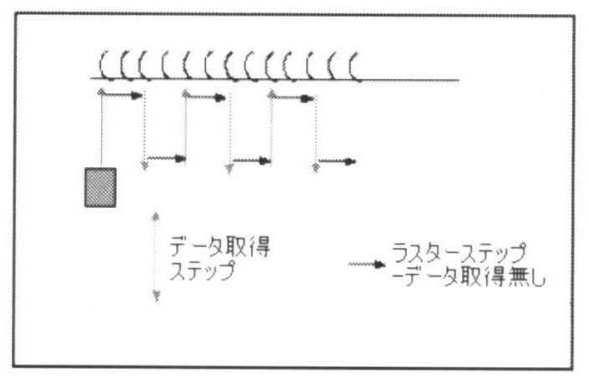

図6a一般のラスタースキャン

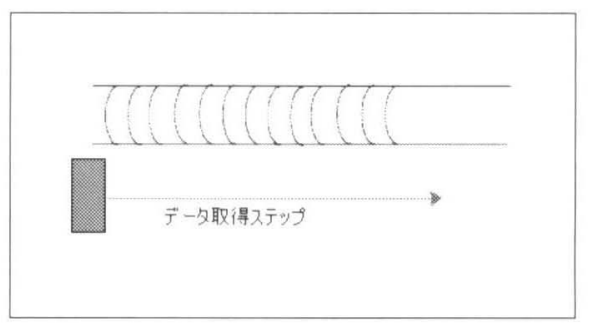

図6b リニアスキャン

機分野のチタニウム鋳造品などに対し特に効果的です.

さらにこの方式の探傷は検査対象の溶接部に対し特定 の入射角度が要求される場合に有用で, これらのアプリ ケーションでは超音波ビームが特定のビーム角で特定の 位置にある溶接部に向かうようプログラムできます。

\section{7. 溶接部のリニアスキャン}

手動の溶接部の UT 検查では, 1 個のトランスデュー サーをオペレーターが前後にスキャンして検査領域をカ バーします（図 6 )。自動化された溶接検査システムでも 大部分が手動探傷と同様の経路をたどったスキャンが行 われますが，この方式ではスキャンのはじめと終わりに トランスデューサー移動の為のデッドタイムゾーンが生 じ時間の無䭾が生じます。

マルチトランスデューサーシステムやフェイズドアレ イでは, 手動より単純化されたりニアスキャンが一般的 です (図 $6 \mathrm{~b}$ ). その場合, プローブホルダは溶接の周辺 または溶接に沿って直線的に移動し, 各トランスデュー サーが検査域をカバーしてスキャンするよう動きます.

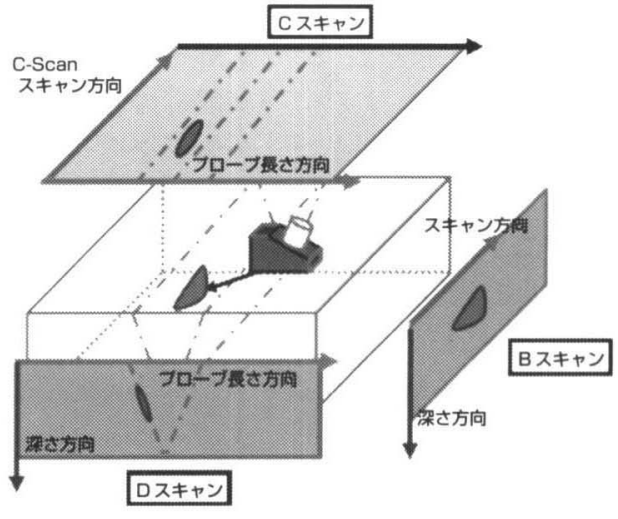

図 7 各画像の説明

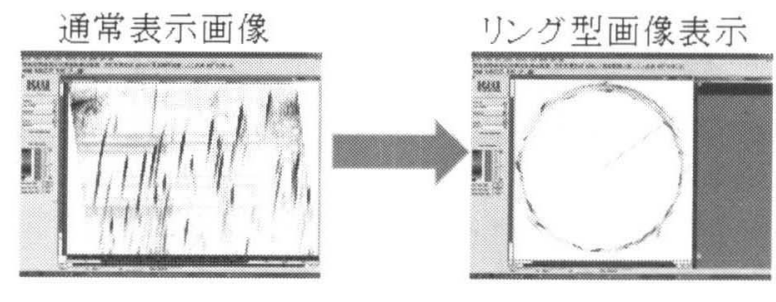

図8 画像処理の一例

リニアスキャンの最も単純な適用例は, 数個のトラン スデューサーによるパイプ製造工場の ERW（電気抵抗溶 接）溶接の検査です。パイプ製造ラインで用いられる探 触子部には, 最大では 24 個のトランスデューサーが装着 され，単独のトランスデューサーによる探傷に較べはる かに高速で検査出来ます.

直線溶接部検査用のフェイズドアレイは, マルチトラ ンスデューサーと原理的に同じ動作です.しかしながら フェイズドアレイでは, 従来の機械式のUTよりはるか にフレキシビリティーがあります.フェイズドアレイで はセットアップの変更はプログラムを変更するだけです.

セットアップの変更や別のセットアップへの積み替え も簡単です.

またフェイズドアレイでは, 従来のトランスデューサ 一と同質のビームを所定の入射角で数多く発生させるこ とが可能です. 特殊な検査もあらかじめ作成したセット アップファイルをロードすることによって容易に実施で きます.

\section{8. 超音波データの画像化}

従来の UT 検査では波形でのデー夕解析が主流で, 熟 練者とそうでない者とでの評価が変わることもあります. フェイズドアレイは前項にて述べた様々な利点に加えて, 波形の画像処理技術に優れている点も挙げられます。こ れは, 全波形をコンピューター上に取込み画像化（可視 化）する技術で, 上面図（Cスキャン）・側面図（B ス キャン）・端面図（Dスキャン）の画像化, さらには任 意の点での断面図・横断面図の画像化が可能です (図 7 ).

また，高度ソフトウェアを使用することにより，パイ プの周溶接部をパイプ状に画像処理する技術（図8）や, 
3D 画像処理等も可能となります.

このような画像処理は, デー夕解析の大きな手助けと なりますし, 解析者によるデー夕解析の相違も極力小さ くすることが出来ます。 また, 全波形を取込んで画像処 理をしているので, 任意の位置での波形もリアルタイム に表示することができ, 従来の波形によるデータ解析も もちろん可能です。

\section{9. 代表的な適用例}

超音波フェイズドアレイは産業の各方面に適用されて， それぞれに有用に利用されています。

主な産業分野は, 航空宇宙, 原子力, 製鋼所, パイプ ミル, 石油化学プラント, パイプラインなどが各分野に 広がり，それぞれにフェイズドアレイ=PA（Phased Array）の持つ特徴が効率的に発揮されています.

・速 度：フェイズドアレイのスキャン速度は, より広 い範囲をカバーしても従来のトランスデューサーを用 いた機械的なスキャンにより一桁以上高速です.

・柔軟性：セットアップは数分で変更できます。さらに 複雑な検查対象にもせットアッププログラムだけで柔 軟に対応できる適用性に優れます。

・検査角度：広範囲の検査角度やマルチビームが要求さ れる場合でも, アレイの配列とタイムデイレイを考慮 することによって容易に対応できます。

・プローブが小型：従来のブローブでは配置する位置の 制限を受ける場合でも，フェイズドアレイではプロー
ブの位置の制限を受けることが殆どありません，また マトリタスアレイプローブなど小型のプローブ郡が用 意され, 従来のトランスデューサーよりはるかにフレ キシブルに広範囲の検査対象に対応できます。

・これらフェイズドアレイの特徴は, その特徴を必要と する検查分野で有用に活用されています, 例えば「速 度」は検査対象が大量にあるパイプアルミやパイプラ インの溶接検査にとって重要です.

・「検査角度」はパイプライン, 航空宇宙分野や原子力 プラントのタービンブレードのような椱雑形状部品を 対象とする分野で特に重視されます.「プローブが小型」 であることは，タービンローターやブレードの検查に 有用であるのみならず，パイプラインの検査時には塗 料剥離を必要とする面積を最小限にできます。

・超音波フェイズドアレイ探傷は、マルチトランスデュ ーサーシステムよりはるかに優れますが，これらは新 しく開発された技術なので一層の実施例の蓄積が必要

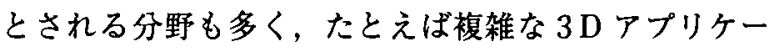
ションへの適用などではセットアップに工夫の余地を 残します. $2 \mathrm{D}$ パイブラインなどのセットアップ容 易です。

\section{参考文献}

Michael Moles, Andre Lamarre and Noel Dube. "Ultrasonic Phased Arrays" (2002), ppl-5. 